\title{
Characteristics and Detection Rate of SARS-CoV-2 in Alternative Sites and Specimens Pertaining to Dental Practice: An Evidence Summary
}

\author{
Sajjad Shirazi ${ }^{1, *(\mathbb{D})}$, Clark M. Stanford ${ }^{2}$ and Lyndon F. Cooper $^{1}$ \\ 1 Department of Oral Biology, College of Dentistry, University of Illinois at Chicago, $801 \mathrm{~S}$ Paulina St, \\ Chicago, IL 60612, USA; cooperlf@uic.edu \\ 2 Department of Restorative Dentistry, University of Illinois at Chicago, Chicago, IL 60612, USA; \\ cmstan60@uic.edu \\ * Correspondence: s.shirazi.tbzmed88@gmail.com
}

check for updates

Citation: Shirazi, S.; Stanford, C.M.; Cooper, L.F. Characteristics and Detection Rate of SARS-CoV-2 in Alternative Sites and Specimens Pertaining to Dental Practice: An Evidence Summary. J. Clin. Med. 2021 10, 1158. https://doi.org/10.3390/ jcm10061158

Academic Editor:

Hans-Peter Howaldt

Received: 6 February 2021

Accepted: 8 March 2021

Published: 10 March 2021

Publisher's Note: MDPI stays neutral with regard to jurisdictional claims in published maps and institutional affiliations.

Copyright: (c) 2021 by the authors. Licensee MDPI, Basel, Switzerland. This article is an open access article distributed under the terms and conditions of the Creative Commons Attribution (CC BY) license (https:/ / creativecommons.org/licenses/by/ $4.0 /)$.

\begin{abstract}
Knowledge about the detection potential and detection rates of severe acute respiratory syndrome coronavirus 2 (SARS-CoV-2) in various body fluids and sites is important for dentists since they, directly or indirectly, deal with many of these fluids/sites in their daily practices. In this study, we attempt to review the latest evidence and meta-analysis studies regarding the detection rate of SARS-CoV-2 in different body specimens and sites as well as the characteristics of these sample. The presence/detection of SARS-CoV-2 viral biomolecules (nucleic acid, antigens, antibody) in different clinical specimens depends greatly on the specimen type and timing of collection. These specimens/sites include nasopharynx, oropharynx, nose, saliva, sputum, bronchoalveolar lavage, stool, urine, ocular fluid, serum, plasma and whole blood. The relative detection rate of SARSCoV-2 viral biomolecules in each of these specimens/sites is reviewed in detail within the text. The infectious potential of these specimens depends mainly on the time of specimen collection and the presence of live replicating viral particles.
\end{abstract}

Keywords: dentistry; RT-PCR testing; antigen; antibody; saliva; aerosols; body fluids; viral load; epidemiological monitoring; COVID-19

\section{Introduction}

Human viral infection and transmission can occur through multiple routes, including exposure to infected blood, exchange of saliva or aerosols generated from sneezing, coughing or dental procedures, fecal-oral, ingestion of contaminated food and drinks and sexual contact. Common examples of viruses isolated from the oral cavity include coronavirus, norovirus, human immunodeficiency virus (HIV), rotavirus, hepatitis C virus, influenza viruses herpes simplex viruses 1 and 2 and Epstein-Barr virus [1].

The cause of the coronavirus disease 2019 (COVID-19) is the severe acute respiratory syndrome coronavirus 2 (SARS-CoV-2), which is an enveloped, positive-sense singlestranded ribonucleic acid (RNA) virus (+ssRNA). The genome encodes 27 proteins including a number of non-structural proteins, including an RNA-dependent RNA polymerase $(\operatorname{RdRP})$, putative accessory proteins and four structural proteins, named as surface or spike glycoprotein (S), envelope protein (E), membrane protein (M) and nucleocapsid (N) proteins. The virus binds to an angiotensin-converting enzyme 2 (ACE2) receptor through $S$ protein for host cell entry. The virus also has an RNA proofreading mechanism keeping the mutation rate relatively low.

The practice of dentistry necessitates a close contact between the dentist, patient and dental healthcare personnel for patient care and procedure support. In addition, the use of rotary and ultrasonic instruments as well as air-water syringes create aerosols containing particle droplets of water, saliva, blood, microorganisms and other debris. Therefore, 
the dental setting is a unique environment in the current pandemic since it potentially possesses all transmission risk factors for SARS-CoV-2 virus, as stated by the Centers for Diseases Control and Prevention (CDC). Accordingly, SARS-CoV-2 mainly spreads between people who are in close contact with each other (within 6 feet or $2 \mathrm{~m}$ ) through respiratory droplets from an infected person. It can linger in aerosols for hours and be spread by people who are not showing symptoms. SARS-CoV-2 can sometimes be spread by airborne transmission within enclosed spaces that have inadequate ventilation within distances more than 6 feet. Contact with contaminated surfaces is another potential transmission route. The infection occurs when the virus is inhaled or deposited on mucous membranes, including that of the nose and mouth [2,3]. Currently, there is no data available to assess the risk of SARS-CoV-2 transmission during dental practice [4,5].

In a recent survey of 849 Italian dentists, a high level of concern for in-office transmission was noted. Dentists perceive needed improvement and change in screening, hygiene and testing patients for SARS-CoV-2 [6]. The Delphi mythology was used among 197 Latin American implant experts to define the importance placed on minimization of disease transmission [7]. When French dental professionals were surveyed early in the pandemic, laboratory-confirmed prevalence of COVID-19 was $1.9 \%$ among dentists. Interestingly, practice limited to endodontics (implying general use of rubber dam) was associated with reduced odds of disease [8]. The importance of protecting oral health workers was underscored. A US survey among dentists conducted in June 2020 indicated that $16.6 \%$ of participants were tested using respiratory and blood samples, and demonstrated a $0.9 \%$ infection rate [9]. A narrative review of Canadian protocols to reduce disease transmission in the dental office included eight different areas involving administrative, physical and procedural controls. The absence of testing was noted as a potential limitation of practice [10].

The presence/detection of SARS-CoV-2 viral biomolecules (nucleic acid, antigens, antibody) in different clinical specimens has been documented based on the type of fluid or material and timing of collection relative to the onset of infection [11]. An infected individual takes an average of 5-6 days (range, 1-14 days) following exposure to develop symptoms (incubation period). The virus may be detectable in the upper respiratory tract 1-3 days before the onset of symptoms, facilitating pre-symptomatic or asymptomatic transmission, but its load is highest around the time of symptom onset, after which it gradually declines $[12,13]$. Reports recommend that upper respiratory tract samples may have higher infectivity early in the course of the disease ( $0-5$ days), after which the virus starts moving towards the lower parts of the respiratory system. Lower respiratory tract samples may have higher viral load later in the course of disease [14].

Current guidance from the World Health Organization (WHO) suggests that the detection of SARS-CoV-2 depends on the testing method, clinical presentation and time since symptom onset [13]. The CDC considers nasopharyngeal, oropharyngeal, nasal and saliva samples to have high viral load and infectivity [15]. In addition, positive detection of SARS-CoV-2 in other clinical samples including sputum, fecal matter, urine, ocular fluid and blood has also been highlighted [16].

In this report, we attempt to review the latest evidence regarding the detection rate of SARS-CoV-2 in different body specimens and sites. The knowledge of the detection rate and the infectivity potential of these specimens is essential. This is of particular importance for dentists because they, in their daily practices, directly or indirectly deal with these specimens/sites which might be the port of entry, or replication and transmission site for SARS-CoV-2.

\section{Detection of COVID-19 in Alternative Samples/Sites}

While SARS-CoV-2 can be detected in a wide range of body fluids and compartments, saliva and respiratory samples remain the main choice for diagnostics. Table 1 summarizes the characteristics of the alternative specimens/sites. 


\subsection{Nasopharynx/Oropharynx}

The nasopharynx and oropharynx are main detection sites in early-stage infection of SARS-CoV-2 in both symptomatic and asymptomatic cases. The peak of viral load in nasopharyngeal samples occurs within the first few days after symptom onset. A special type of swabs (flocked swab, synthetic fiber swabs with plastic shafts) is used as the sample collection tool. Calcium alginate swabs or those with wooden shafts are not recommended since they may interfere with nucleic acid amplification tests (NAATs) or contain substances which inactivate the virus [17]. While dependent on the viral load, nasopharyngeal samples are generally more sensitive than oropharyngeal samples. However, the number of days passed since the onset of symptoms and disease stage influence positive testing $[13,18-20]$. The infectivity potential of both specimens has been demonstrated [21].

In a meta-analysis of studies comparing at least two respiratory specimen types (oropharyngeal, nasopharyngeal or sputum), the overall positive detection rate with NAATs in confirmed patients was estimated to be $43 \%$ (95\% confidence interval (CI): $34-52 \%)$ for oropharyngeal swabs and 54\% (95\% CI: 41-67\%) for nasopharyngeal swabs. The estimated percentage of positive tests were $75 \%$ (95\% CI: $60-88 \%$ ) between days $0-7,35 \%$ (95\% CI: $27-43 \%$ ) between days $8-14$ and $12 \%$ (95\% CI: $2-25 \%$ ) after 14 days from symptom onset for oropharyngeal swab sampling. For nasopharyngeal swabs, this figure was $80 \%$ (95\% CI: $66-91 \%), 59 \%$ (95\% CI: 53-64\%) and 36\% (95\% CI: $18-57 \%$ ) at $0-7,8-14$ and $>14$ days after symptom onset, respectively [20].

A recent meta-analysis of studies comparing paired oropharyngeal and nasopharyngeal samples in confirmed cases found a similar positive detection rate between oropharyngeal and nasopharyngeal swabs ( $84 \%$ (95\% CI: $57-100 \%$ ) vs. $88 \%$ (95\% CI: 73-98\%), respectively) using NAATs. Importantly, there is limited agreement between tests from these sites as the percent of individuals positive for both specimens was only $68 \%$ (95\% CI: 36-93\%) [22]. Nevertheless, combining swabs from both sites has been shown to improve sensitivity and reliability of the results [13]. In addition, a meta-analysis of studies investigating the clinical performance of antigen tests not requiring a separate reading device in confirmed COVID-19 patients revealed a pooled sensitivity of 0.747 (95\% CI: $0.673-0.809$ ) for nasopharyngeal or combined oro/nasopharyngeal samples [23].

There are some contraindications for collection of nasopharyngeal samples, including coagulopathy or anticoagulant therapy, and significant nasal septum deviation [24]. Swabs should be placed immediately into a sterile transport tube containing 2-3 $\mathrm{mL}$ of either viral transport medium (VTM), Amies transport medium, phosphate-buffered saline, or sterile saline, unless using a test designed to analyze a specimen directly (i.e., without placement in VTM) (Table 1).

\subsection{Nasal}

Nasal specimen may be obtained with swabs from two anatomical sites, nasal midturbinate (deep nasal) and anterior nares, or with nasal wash/aspirate [15]. There is currently no strong evidence regarding SARS-CoV-2 overall positive detection rate in nasal wash compared to other methods. However, Calame et al. [25] compared nasal wash and nasopharyngeal swab sampling and concluded that these methods have comparable clinical and analytical sensitivity.

A meta-analysis of studies comparing paired nasal (either mid-turbinate or anterior nares) and nasopharyngeal samples for NAATs in confirmed cases found that nasal swabs had substantially lower positive detection rate than the nasopharyngeal samples ( $82 \%$ (95\% CI: $73-90 \%$ ) vs. $98 \%$ (95\% CI: $96-100 \%)$, respectively). The percent of individuals positive for both specimens was only 79\% (95\% CI: 69-88\%), suggesting limited agreement. Nasal specimens collected from a single nostril seemed to perform better in comparison to swabs collected from both nares [22]. In addition, studies of only symptomatic patients had a similar positive detection rate for nasal samples as compared to studies of mixed patients. Ultimately, the use of more sensitive assays (limit of detection $<1000$ copies/milliliter) for nasal samples resulted in lower positive detection in comparison to assays with limit of 
detection $\geq 1000$ copies $/ \mathrm{mL}$. However, this figure was not affected by assay sensitivity in nasopharyngeal samples. This reflects lower viral burden in the mid-turbinate/anterior nares region than the nasopharynx, resulting in lower performance when using highly sensitive assays [22].

A meta-analysis of studies that compared combined oropharyngeal-nasal swabs and nasopharyngeal swabs for NAATs in confirmed cases found an identical positive detection rate (97\% (95\% CI: 90-100\%)) between the two methods. The percent of individuals positive for both specimens was also high (90\% (95\% CI: 84-96\%)) [22].

\subsection{Saliva}

The detection of SARS-CoV-2 through oral shedding and especially in saliva has been shown. The infectivity potential of saliva has also been well-demonstrated [26]. SARSCoV-2 viral load in saliva may be a good indicator of the transmission potential of infected patients, since it is highest during the first week of infection, during which a person is most infectious.

Saliva has been shown to yield greater detection sensitivity and consistency throughout the course of infection than the nasopharyngeal samples [18,27-30]. Positive detection rate with NAATs in confirmed cases for saliva samples vary greatly in the literature but is estimated to be higher than $80 \%$ [11,31]. A recent meta-analysis of studies comparing paired saliva and nasopharyngeal samples in confirmed cases estimated a positive detection rate of $88 \%$ (95\% CI: 81-93\%) and 94\% (95\% CI: 90-98\%) respectively, with no statistically significant difference. The percent of individuals positive for both the specimens was 79\% (95\% CI: 71-86\%), indicating relatively poor agreement [22]. This study also demonstrated that positive detection rate with NAATs after 7 days from symptom onset was lower compared to $\leq 7$ days (74\% (95\%CI: $62-85 \%$ ) vs. $89 \%$ (95\% CI: 73-99\%)), which was also observed for nasopharyngeal swabs in the same patients $(91 \%$ (95\% CI: 82-98\%) vs. 99\% (95\% CI: 90-100\%), respectively) [22]. Another meta-analysis estimated an overall diagnostic accuracy of $92.1 \%$ (95\% CI: 70-98.3\%), with sensitivity of $83.9 \%$ (95\% CI: 77.4-88.8\%) and specificity of $96.4 \%$ (95\% CI: 89.5-98.8) for saliva samples in comparison to nasopharyngeal/oropharyngeal samples in confirmed cases [32]. The sensitivity of saliva was estimated to be $3.4 \%$ lower $(-3.4 \%, 95 \%$ CI: $-9.9-3.1 \%)$ than that of nasopharyngeal swabs in another recent meta-analysis [33].

The differences in sensitivity of oral fluids' evaluations are possibly because of large differences in collection, transport, storage and processing techniques, as well as the evaluation of different testing populations and disease stage. Collection methods included spitting or drooling, coughing or clearing throat, collection with pipet or special sponges and gargling with saline solutions $[22,24]$. It is likely that a simple drooling technique, with no extra stimulation of saliva secretion, will provide the greatest sensitivity [24]. In addition, many studies have supported the hypothesis of coughing (likely mixed sputum and saliva specimen) or deep throat saliva being better than drool/spit. However, considerable differences have not been revealed [22].

Another difference among studies is sample collection in the morning, or avoidance of eating, drinking, or brushing teeth (30 min to $2 \mathrm{~h}$ before specimen collection), which lead to a slightly higher positive detection rate. The variable dilution of saliva prior to processing is another difference among the studies. However, the positivity rate is similar in studies utilizing diluted or undiluted saliva samples. Moreover, studies that directly input the saliva specimen into the amplification assay without any pre-processing showed substantially lower positive detection than those which used a nucleic acid extraction step. Additionally, a positive detection rate in saliva samples was shown to be similar between asymptomatic and symptomatic patients [22]. Ultimately, no substantial difference was detected among studies that used assays with low ( $<1000$ copies/milliliter) or high limit of detection for saliva samples, which demonstrates high viral load in saliva samples [22].

To optimize saliva-based testing and obtain a reliable and sensitive result, a specific, standard and optimized saliva collection and transportation method should be utilized. 
Also, an optimal solution should be used to collect, transport and store saliva samples. In addition, the RNA isolation and detection protocol should be optimized for saliva, using an appropriate internal control. The use of human DNA is suggested for nasopharyngeal samples but not for saliva samples [24]. The use of saliva samples is quicker, less painful and invasive and allows for higher volume testing, and collection by the patient at home or clinic without posing risks to healthcare providers. Sample includes $1-5 \mathrm{~mL}$ of saliva in a sterile, leak-proof screw cap container, with no preservative required (Table 1). The simplicity of saliva-based testing for large populations must be weighed against the reported differences in sensitivity when compared to nasopharyngeal samples.

\subsection{Sputum}

Sputum is mucus produced in the respiratory tract (the trachea and bronchi) and is collected by coughing up deeply and spitting out directly into a sterile, leak-proof, collection cup. It is indicated later in the course of the COVID-19 disease or in patients with a negative upper respiratory sample result while there is a strong clinical suspicion of COVID-19 [13]. The overall positive detection rate with NAATs in confirmed cases for sputum samples was estimated by a recent meta-analysis to be $71 \%$ (95\% CI: $61-80 \%$ ), which was significantly higher than that of nasopharyngeal and oropharyngeal samples in the same study. More specifically, the estimated percentage of COVID-19-positive samples was $98 \%$ (95\% CI: $89-100 \%$ ), $69 \%$ (95\% CI: $57-80 \%$ ) and $46 \%$ (95\% CI: $23-70 \%$ ) at $0-7$ days, 8-14 days and $>14$ days after symptom onset, respectively [20]. In another meta-analysis, an overall accuracy of 79.7\% (95\% CI: 43.3-95.3\%), sensitivity of 90.1\% (95\% CI: 83.3-96.9\%) and specificity of $63.1 \%$ (95\% CI: 36.8-89.3\%) was estimated for deep-throat saliva/posterior oropharyngeal saliva samples in comparison to nasopharyngeal/oropharyngeal samples in confirmed cases [32].

The infectivity and transmissibility potential of sputum has been demonstrated [21]. If spontaneously produced, sputum collection is an easier process than swab sampling and can easily be done by the patient. The collection of coughed or spit samples carries the potential added risk of transmission by aerosolization [13] (Table 1).

\subsection{Bronchoalveolar Lavage}

Bronchoalveolar lavage is generally collected later in the course of COVID-19, from patients with severe illness or undergoing mechanical ventilation or to determine the recovery of admitted patients [13]. A meta-analysis revealed that it has a positive detection rate of $91.8 \%$ (95\% CI: $79.9-103.7 \%$ ) by NAATs, which was higher than that of sputum and nasopharyngeal specimen in the same review [34]. Collecting bronchoalveolar lavage is complex and with high risk of aerosolization. It includes the instillation of sterile normal saline into a sub-segment of the lung, followed by suction and collection. Endotracheal aspiration has a lower risk of aerosolization than bronchoalveolar lavage with comparable sensitivity and specificity [43] (Table 1). 
Table 1. Characteristics of the alternative specimens/site for detection of severe acute respiratory syndrome coronavirus 2 (SARS-CoV-2).

\begin{tabular}{|c|c|c|c|c|c|c|c|c|c|c|}
\hline Site/Fluid & $\begin{array}{l}\text { Collection } \\
\text { Method }^{1}\end{array}$ & Self-Sampling & $\begin{array}{c}\text { Infectivity } \\
\text { Potential }\end{array}$ & $\begin{array}{l}\text { Analyte } \\
\text { Detected }\end{array}$ & $\begin{array}{l}\text { Detection } \\
\text { Method }^{2}\end{array}$ & $\begin{array}{c}\text { Analyte } \\
\text { Load }\end{array}$ & $\begin{array}{l}\text { Approximate } \\
\text { Time to Peak }\end{array}$ & Relative Detection Rate $^{3}$ & Advantage & Disadvantage \\
\hline Nasopharynx & $\begin{array}{l}\text { Synthetic fiber } \\
\text { swabs with plastic } \\
\text { or wire shafts with }\end{array}$ & $\begin{array}{l}\text { No, healthcare } \\
\text { personnel } \\
\text { preferred }\end{array}$ & Yes & $\begin{array}{l}\text { Nucleic } \\
\text { acid } \\
\text { Viral } \\
\text { antigen }\end{array}$ & $\begin{array}{l}\text { NAATs } \\
\text { IA }\end{array}$ & High & $\begin{array}{c}0-7 \text { days after } \\
\text { symptom onset }\end{array}$ & $54 \%$ (95\% CI: 41-67\%) [20] & Gold standard specimen & $\begin{array}{l}\text { Needs trained personnel. } \\
\text { Procedure is painful and not easy. } \\
\text { Not suitable in individuals prone } \\
\text { to nose bleeds or has had recent } \\
\text { facial or head injury/surgery }\end{array}$ \\
\hline Oropharynx & $\begin{array}{c}\text { Synthetic fiber } \\
\text { swabs with plastic } \\
\text { or wire shafts }\end{array}$ & $\begin{array}{l}\text { Possibly, } \\
\text { healthcare } \\
\text { personnel } \\
\text { preferred }\end{array}$ & Yes & $\begin{array}{l}\text { Nucleic } \\
\text { acid }\end{array}$ & NAATs & High & $\begin{array}{l}0-7 \text { days after } \\
\text { symptom onset }\end{array}$ & $43 \%$ (95\% CI: 34-52\%) [20] & Easy to operate & $\begin{array}{l}\text { Less sensitive than } \\
\text { nasopharyngeal swab and sputum. }\end{array}$ \\
\hline $\begin{array}{l}\text { Nasal } \\
\text { (mid-turbinate } \\
\text { or anterior } \\
\text { nares) }\end{array}$ & $\begin{array}{l}\text { Flocked or spun } \\
\text { polyester swab }\end{array}$ & Yes & Yes & $\begin{array}{l}\text { Nucleic } \\
\text { acid } \\
\text { Viral } \\
\text { antigen }\end{array}$ & $\begin{array}{l}\text { NAATs } \\
\text { IA }\end{array}$ & Average & $\begin{array}{l}0-7 \text { days after } \\
\text { symptom onset }\end{array}$ & $82 \%$ (95\% CI: 73-90\%) [22] & $\begin{array}{l}\text { Minimally invasive. } \\
\text { Lower risk for healthcare } \\
\text { infection }\end{array}$ & $\begin{array}{l}\text { Less sensitive if not collected } \\
\text { correctly. Not suitable in } \\
\text { individuals prone to nose bleeds or } \\
\text { has had recent facial or head } \\
\text { injury/surgery }\end{array}$ \\
\hline Sputum & Sterile container & Yes & Yes & $\begin{array}{l}\text { Nucleic } \\
\text { acid }\end{array}$ & NAATs & $\begin{array}{l}\text { Average- } \\
\text { high }\end{array}$ & $\begin{array}{l}3-7 \text { days after } \\
\text { symptom onset }\end{array}$ & 71\% (95\% CI: 61-80\%) [20] & $\begin{array}{l}\text { High yield compared to } \\
\text { upper respiratory swab }\end{array}$ & $\begin{array}{l}\text { High risk of infection for operators. } \\
\text { The high viscosity of sputum } \\
\text { makes it difficult to extract nucleic } \\
\text { acids. }\end{array}$ \\
\hline Saliva & Sterile container & Yes & Yes & $\begin{array}{c}\text { Nucleic } \\
\text { acid }\end{array}$ & NAATs & High & $\begin{array}{l}\text { 3-7 days after } \\
\text { symptom onset }\end{array}$ & $>80 \%[11,20,31]$ & $\begin{array}{l}\text { Not invasive. Less risk } \\
\text { for healthcare infection. } \\
\text { Large amount of sample }\end{array}$ & $\begin{array}{l}\text { Less sensitive if not collected } \\
\text { correctly. False negative results }\end{array}$ \\
\hline $\begin{array}{l}\text { Broncho- } \\
\text { alveolar lavage } \\
\text { fluid }\end{array}$ & Sterile container & No & Yes & $\begin{array}{l}\text { Nucleic } \\
\text { acid }\end{array}$ & NAATs & Medium & $\begin{array}{l}7-14 \text { days after } \\
\text { symptom onset }\end{array}$ & $\begin{array}{c}91.8 \% \text { (95\% CI: 79.9-103.7\%) } \\
\text { [34] }\end{array}$ & $\begin{array}{l}\text { High detection rate/low } \\
\text { limit of detection }\end{array}$ & High risk of cross-infection \\
\hline Stool & Stool container & Yes & $\begin{array}{l}\text { Not fully } \\
\text { clear }\end{array}$ & $\begin{array}{l}\text { Nucleic } \\
\text { acid }\end{array}$ & NAATs & Medium & $\begin{array}{l}>14 \text { days after } \\
\text { symptom onset }\end{array}$ & $\begin{array}{c}51.8 \% \text { (95\% CI: } 43.8-59.7 \%) \\
\text { [35] }\end{array}$ & $\begin{array}{l}\text { Less risk for healthcare } \\
\text { infection. } \\
\text { Non-invasive }\end{array}$ & $\begin{array}{l}\text { Might be confined to later-stage } \\
\text { infection diagnosis }\end{array}$ \\
\hline Urine & Collection tube & Yes & $\begin{array}{l}\text { Not fully } \\
\text { clear }\end{array}$ & $\begin{array}{l}\text { Nucleic } \\
\text { acid }\end{array}$ & NAATs & Low & 16-21 days & $\begin{array}{c}5.74 \% \text { (95\% CI: } 2.88-9.44 \%) \\
\text { [36] }\end{array}$ & $\begin{array}{l}\text { Non-invasive sample } \\
\text { collection }\end{array}$ & Limited data has been studied \\
\hline Ocular fluid & $\begin{array}{c}\text { Tear or } \\
\text { conjunctival swab }\end{array}$ & $\begin{array}{l}\text { Possibly, } \\
\text { healthcare } \\
\text { personnel } \\
\text { preferred }\end{array}$ & $\begin{array}{l}\text { Not fully } \\
\text { clear }\end{array}$ & $\begin{array}{l}\text { Nucleic } \\
\text { acid }\end{array}$ & NAATs & Low & Unclear & $0-28.57 \%[37-40]$ & $\begin{array}{l}\text { Non-invasive sample } \\
\text { collection }\end{array}$ & No conclusive data available \\
\hline Blood & $\begin{array}{c}\text { Collection tube } \\
\text { with anticoagulant }\end{array}$ & No & $\begin{array}{l}\text { Not fully } \\
\text { clear }\end{array}$ & $\begin{array}{l}\text { Nucleic } \\
\text { acid } \\
\text { Antibody }\end{array}$ & $\begin{array}{l}\text { NAATs } \\
\text { IA }\end{array}$ & Low & $\begin{array}{l}\text { 5-14 days for } \\
\text { nucleic acid } \\
>10 \text { days for } \\
\text { antibody }\end{array}$ & $\begin{array}{l}\text { 10\% (95\% CI: } 5-18 \% \text { ) for } \\
\text { nucleic acid [41] }\end{array}$ & $\begin{array}{l}\text { Easy to operate, low } \\
\text { infectious concern }\end{array}$ & $\begin{array}{l}\text { High false negative rate. High } \\
\text { limit of detection. }\end{array}$ \\
\hline Serum & $\begin{array}{l}\text { Serum separator } \\
\text { tubes }\end{array}$ & No & low & Antibody & IA & High & $\begin{array}{l}>14 \text { days for } \\
\text { antibody detection }\end{array}$ & $\begin{array}{c}\text { 61.2\% (95\% CI: } 53.4-69.0 \%) \\
\text { for IgM, 58.8 (95\% CI: } \\
49.6-68.0 \%) \text { for IgG, and } \\
\text { 62.1\% (52.7-71.4\%) for } \\
\text { IgM-IgG [42] }\end{array}$ & $\begin{array}{l}\text { Rapid, simple and } \\
\text { convenient. Sample is } \\
\text { more stable. Low } \\
\text { cost. Suitable for disease } \\
\text { surveillance. }\end{array}$ & $\begin{array}{l}\text { Low sensitivity in the early stage } \\
\text { of disease. High false negative rate. } \\
\text { Cross-reactivity of antibody and } \\
\text { false positive. }\end{array}$ \\
\hline
\end{tabular}

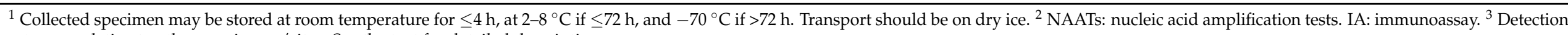
rates are relative to other specimens/sites. See the text for detailed description. 


\subsection{Stool}

Fecal shedding of respiratory viruses is not uncommon and stool samples may contain large viral loads of SARS-CoV-2 at early onset through the convalescent stage of illness. The World Health Organization (WHO) recommends for stool diagnostic testing to be considered from the second week after symptom onset and onwards, suggesting that this positivity is prolonged compared to that of respiratory tract specimens [13]. Detection rate of SARS-CoV-2 RNA in fecal specimens (excluding anal or rectal swabs) among patients with confirmed diagnosis has been estimated to be $43.7 \%$ (95\% CI: $32.6-55.0 \%$ ) in a metaanalysis [44]. This figure was 51.8\% (95\% CI: $43.8-59.7 \%)$ in the most recent meta-analysis which used different inclusion criteria, and also, did not exclude anal or rectal swabs. It was estimated that $64 \%$ of tested individuals had persistent positive fecal specimens test despite negative respiratory tests for a mean duration of 12.5 days after negative respiratory testing [35]. Importantly, it has been reported that SARS-CoV-2 viral shedding in stool may persist up to 6 weeks after symptom onset [36]. An overall diagnostic sensitivity of $46.0 \%$ (95\% CI: $13.1-82.7 \%$ ) and specificity of $91.4 \%$ (95\% CI: 6.4-99.9\%) has been estimated for feces/anal swab in comparison to nasopharyngeal/oropharyngeal samples in confirmed cases [32].

Fecal-oral transmission is an accepted mode of transmission for other coronaviruses such as SARS-associated coronavirus (SARS-CoV) and Middle East respiratory syndrome coronavirus (MERS-CoV) [45]. Detection of live active SARS-CoV-2 virus in stool samples has been reported in the literature, underlining the possibility of fecal-oral transmission through infected feces. However, it is unclear if the positive fecal test results are due to active virion particles or inactive viral RNA amplified by polymerase chain reaction (PCR). Therefore, the infectivity and transmissibility potential of stool has not been established $[21,28,35,45]$. Fecal specimens are suggested to be tested concurrently with other samples to detect false-positives and/or monitor disease progression.

Nevertheless, the viral detection rate could vary substantially due to the presence of PCR inhibitors (bile, polysaccharides, hemoglobin and bilirubin) which make the process of viral detection very difficult, susceptible to user error and requiring trained technicians and special RNA extraction kits $[17,18,46,47]$. Sample collection is simple and can often be performed at home by capturing a stool sample (about $10 \mathrm{~g}$ or peanut size) in a dry and clean container and transferring into a sterile specimen cup (Table 1).

\subsection{Urine}

Urinary shedding of SARS-CoV-2 has been highly correlated with disease severity in adults. A recent meta-analysis revealed that the frequency of viral shedding was $4.5 \%$ with a weighted pooled estimate of $1.18 \%$ (95\% CI: $0.14-2.87 \%$ ) after excluding case reports and case series with small sample size ( $<9$ patients) [48]. The overall urinary shedding of SARSCoV-2 in confirmed COVID-19 patients was estimated to be $8 \%$ in another meta-analysis, with a relative risk of 0.08 ( $95 \%$ CI: 0.05-0.16) compared to nasopharyngeal samples, 0.33 (95\% CI: 0.15-0.72) compared to stool samples and 0.20 (95\% CI: 0.14-0.29) compared to blood/serum samples [49]. The pooled rate of urine positivity was $5.74 \%$ (95\% CI: $2.88-9.44 \%$ ) in another meta-analysis based on different inclusion criteria [36]. However, it remains unclear if urine has infectivity and transmissibility potential despite containing viral genetic material $[26,48]$ (Table 1$)$.

\subsection{Ocular Fluid}

Many respiratory viruses are known to enter through eyes or utilize the eye as a replication site before causing a respiratory infection [50]. SARS-CoV-2 has been detected occasionally in tears and conjunctival swabs in confirmed patients, however, the current data is controversial. The positive detection rate varies greatly in the available studies and figures fluctuate from $0 \%$ up to $28.57 \%$ [51-54]. While there are a number of published meta-analysis studies [37-40], their search dates are not recent and may have omitted newly 
published studies. A recent meta-analysis reported an overall sensitivity of $17.4 \%$ (95\% CI: 7.8-34.2\%) and specificity of $96.1 \%$ (95\% CI: $12.7-100 \%)$ for ocular fluid in comparison to nasopharyngeal/oropharyngeal samples in confirmed cases [32].

The optimal time window to detect SARS-CoV-2 on the ocular surface, and whether the viral RNA present in the ocular fluids has infectious potential, is still unclear [17,37]. A standardized sample collection method and additional sampling time points would resolve heterogeneity in positive rates and provide insightful information. It has been noted that conjunctiva, cornea or the epithelial cells of the nasolacrimal duct can take up virus and may be a port of entry or direct inoculation site of infectious droplets, leading to contraction of the infection [53]. This is of significant importance for dentists and oral health professionals due the generation of potentially infectious droplets during dental procedures. The collection method includes the use of conjunctival swabs to collect both exfoliated cells and tears, or Schirmer's test strips to collect tears (Table 1).

\subsection{Serum, Plasma and Whole Blood}

Serum, plasma and whole blood are primarily used in antibody (serology) tests and occasionally for nucleic acid detection for tracking COVID-19 disease progression, severity or prognosis, epidemiological studies and patient immunity [47]. According to the recent meta-analysis of diagnostic performance of serology tests for COVID-19, the pooled sensitivity of Immunoglobin G (IgG), Immunoglobin M (IgM) and combined IgM-IgG tests in confirmed COVID-19 patients was 0.76 (95\% CI: 0.65-0.86), 0.69 (95\% CI: $0.59-0.78$ ) and 0.78 (95\% CI: 0.70-0.85), respectively. Thus, negative serological results alone cannot exclude the diagnosis of COVID-19 [55].

It was further demonstrated that serology tests had the lowest sensitivity at 0-7 days after symptom onset, and the highest sensitivity (more than $85 \%$ ) at $>14$ days, suggesting that serological tests might be useful for diagnosis purposes at later stages of disease. The specificity of IgG, IgM and combined IgM-IgG tests was 0.98 (95\% CI: 0.96-0.99), 0.95 (95\% CI: 0.91-0.98) and 0.97 (95\% CI: 0.93-0.99), respectively [55]. In another meta-analysis, SARS-CoV-2 seropositivity rate was estimated to be $61.2 \%$ (95\% CI: $53.4-69.0 \%$ ) for IgM, $58.8 \%$ (95\% CI: $49.6-68.0 \%$ ) for IgG and 62.1\% (52.7-71.4\%) for IgM-IgG joint detection in confirmed patients. Serologic testing also yielded high values in the identification of asymptomatic infections with a seropositivity rate of $19 \%$ (95\% CI: $10.0-27.0 \%$ ) for combined IgM-IgG [42]. Samples for serology tests are frequently collected by a fingerstick forming the basis for a simple test that can be performed at home by the patient.

SARS-CoV-2 viral RNA has also been detected in blood, serum and plasma samples from patients. A meta-analysis estimated the positive detection rate of viral RNA in blood products up to 28 days following symptomatic onset to be $10 \%$ (95\% CI: 5-18\%) [41], most of which are detected with low copy numbers, at earlier time points and in more severe patients. However, it remains controversial whether the detection of viral RNA in blood samples reflects the presence of infectious virus, as this has important safety implications, especially for dental practitioners and personnel and those handling patient-related materials in clinical, laboratory and research environments [41]. For RNA detection, $5 \mathrm{~mL}$ of anticoagulated blood is required. Vacuum tubes containing ethylenediaminetetraacetic acid (EDTA) anticoagulant are recommended for blood collection (Table 1).

\section{Discussion}

Recommended infection prevention and control practices for dental treatment delivery encourage the elective procedures and non-urgent outpatient visits to be postponed in applicable circumstances, and tele-dentistry and triage protocols to be implemented prior to dental appointments. The next step is to screen and triage everyone entering the dental office for fever and symptoms consistent with COVID-19 or exposure to others with COVID-19 infection. Nevertheless, a fever might only be associated with a dental diagnosis if no other symptoms of COVID-19 are present. The patients should also be requested to contact the dental office if they develop COVID-19 signs or symptoms or are 
diagnosed with COVID-19 within 2 days after the dental appointment [3,56]. However, presymptomatic (before symptom onset), or asymptomatic patients (that account for more than $40 \%$ of confirmed cases), impose a greater challenge than symptomatic patients for dental settings in this process [57]. The high transmissibility of SARS-CoV-2 has been attributed to asymptomatic carriers and pre-symptomatic patients. These patients have similar viral load to that of symptomatic COVID-19 patients, causing comparable transmissibility [58].

There are very limited studies which reported the prevalence of COVID-19 infection among dental patients. Lamberghini et al. [59] reported an overall SARS-CoV-2 positivity rate of $2.3 \%$ in asymptomatic children attending a high-volume pediatric dental practice. Conway et al. [60] reported an overall test positivity rate of $0.6 \%$ (95\% CI: $0.4-0.8 \%$ ) in child and adult asymptomatic patients attending multiple dental care centers. These findings highlight that while dental practices must screen patients for signs and symptoms of COVID-19 and refer patients for appropriate medical follow-up when indicated, such screening alone will not identify all individuals who are infected. Therefore, timely, accurate (highly sensitive and specific) and rapid screening and diagnostic testing that can distinguish COVID-19 cases from healthy or other virus-infected individuals is an essential need to take required actions, optimize patient care, maintain dental patients' and treatment providers' safety and to contain and prevent disease spread. It is being recognized that dental practices would greatly benefit from the ability to evaluate the disease status of their patients by using point-of-care COVID-19 diagnostic tests.

\section{Conclusions}

SARS-CoV-2 can be detected in different body specimens and sites. Dentists, directly or indirectly, deal with many of these specimens/sites in their daily practices. Information regarding prevalence of SARS-CoV-2 virus among asymptomatic individuals is less welldocumented but is significant in future management of the dental environment. The present literature indicates that detection of SARS-CoV-2 and the infectious potential of the tested virus is dependent on the time of specimen collection relative to symptoms/infection and the presence of actual live viral particles.

Author Contributions: Conceptualization, S.S.; methodology, S.S.; validation, S.S. and L.F.C.; formal analysis, S.S.; investigation, S.S.; writing-original draft preparation, S.S.; writing-review and editing, L.F.C. and C.M.S.; supervision, L.F.C.; funding acquisition, L.F.C. and C.M.S. All authors have read and agreed to the published version of the manuscript.

Funding: This research received no external funding.

Data Availability Statement: No new data were created or analyzed in this study. Data sharing is not applicable to this article.

Conflicts of Interest: Authors declare no conflict of interest.

\section{References}

1. Corstjens, P.L.A.M.; Abrams, W.R.; Malamud, D. Saliva and Viral Infections. Periodontol 2000 2016, 70, 93-110. [CrossRef]

2. CDC Coronavirus Disease 2019 (COVID-19)—Transmission. Available online: https://www.cdc.gov/coronavirus / 2019-ncov/ prevent-getting-sick/how-covid-spreads.html (accessed on 3 March 2021).

3. Guerra, F.; Mata, A.D. COVID-19. Normas de Orientação Clínica-Medicina Dentária; Coimbra University Press: Coimbra, Portugal, 2020; ISBN 978-989-26-1986-6. [CrossRef]

4. Ren, Y.; Feng, C.; Rasubala, L.; Malmstrom, H.; Eliav, E. Risk for Dental Healthcare Professionals during the COVID-19 Global Pandemic: An Evidence-Based Assessment. J. Dent. 2020, 101, 103434. [CrossRef] [PubMed]

5. Banakar, M.; Bagheri Lankarani, K.; Jafarpour, D.; Moayedi, S.; Banakar, M.H.; MohammadSadeghi, A. COVID-19 Transmission Risk and Protective Protocols in Dentistry: A Systematic Review. BMC Oral Health 2020, 20, 275. [CrossRef] [PubMed]

6. Amato, A.; Ciacci, C.; Martina, S.; Caggiano, M.; Amato, M. COVID-19: The Dentists' Perceived Impact on the Dental Practice. Eur. J. Dent. 2021. [CrossRef]

7. Alarcón, M.A.; Sanz-Sánchez, I.; Shibli, J.A.; Santos, A.T.; Caram, S.; Lanis, A.; Jiménez, P.; Dueñas, R.; Torres, R.; Alvarado, J.; et al. Delphi Project on the Trends in Implant Dentistry in the COVID-19 Era: Perspectives from Latin America. Clin. Oral Implant. Res. 2021. [CrossRef] [PubMed] 
8. Jungo, S.; Moreau, N.; Mazevet, M.E.; Ejeil, A.-L.; Biosse Duplan, M.; Salmon, B.; Smail-Faugeron, V. Prevalence and Risk Indicators of First-Wave COVID-19 among Oral Health-Care Workers: A French Epidemiological Survey. PLoS ONE 2021, 16, e0246586. [CrossRef] [PubMed]

9. Estrich, C.G.; Mikkelsen, M.; Morrissey, R.; Geisinger, M.L.; Ioannidou, E.; Vujicic, M.; Araujo, M.W.B. Estimating COVID-19 Prevalence and Infection Control Practices among US Dentists. J. Am. Dent. Assoc. 2020, 151, 815-824. [CrossRef]

10. Brondani, M.; Cua, D.; Maragha, T.; Shayanfar, M.; Mathu-Muju, K.; von Bergmann, H.; Almeida, F.; Villanueva, J.; Alvarado, A.A.V.; Learey, S.; et al. A Pan-Canadian Narrative Review on the Protocols for Reopening Dental Services during the COVID-19 Pandemic. BMC Oral Health 2020, 20, 352. [CrossRef]

11. Comber, L.; Walsh, K.A.; Jordan, K.; O’Brien, K.K.; Clyne, B.; Teljeur, C.; Drummond, L.; Carty, P.G.; De Gascun, C.F.; Smith, S.M.; et al. Alternative Clinical Specimens for the Detection of SARS-CoV-2: A Rapid Review. Rev. Med. Virol. 2020. [CrossRef] [PubMed]

12. Linton, N.M.; Kobayashi, T.; Yang, Y.; Hayashi, K.; Akhmetzhanov, A.R.; Jung, S.-M.; Yuan, B.; Kinoshita, R.; Nishiura, H. Incubation Period and Other Epidemiological Characteristics of 2019 Novel Coronavirus Infections with Right Truncation: A Statistical Analysis of Publicly Available Case Data. J. Clin. Med. 2020, 9, 538. [CrossRef] [PubMed]

13. World Health Organization Diagnostic Testing for SARS-CoV-2. Available online: https://www.who.int/publications-detailredirect/diagnostic-testing-for-sars-cov-2 (accessed on 3 March 2021).

14. Dos Santos, C.C.; Zehnbauer, B.A.; Trahtemberg, U.; Marshall, J. Molecular Diagnosis of Coronavirus Disease 2019. Crit Care Explor. 2020, 2. [CrossRef]

15. CDC Interim Guidelines for Collecting, Handling, and Testing Clinical Specimens for COVID-19. Updated December 29. Available online: https:/ / www.cdc.gov/coronavirus/2019-ncov/lab/guidelines-clinical-specimens.html (accessed on 3 March 2021).

16. Ireland Health Information and Quality Authority Evidence Summary for COVID-19 Clinical Samples | HIQA. Available online: https: / / www.hiqa.ie/reports-and-publications/health-technology-assessment/evidence-summary-covid-19-clinicalsamples (accessed on 12 November 2020).

17. Pan, Y.; Zhang, D.; Yang, P.; Poon, L.L.M.; Wang, Q. Viral Load of SARS-CoV-2 in Clinical Samples. Lancet Infect. Dis. 2020, 20, 411-412. [CrossRef]

18. Wang, W.; Xu, Y.; Gao, R.; Lu, R.; Han, K.; Wu, G.; Tan, W. Detection of SARS-CoV-2 in Different Types of Clinical Specimens. JAMA 2020, 323, 1843-1844. [CrossRef]

19. Asselah, T.; Durantel, D.; Pasmant, E.; Lau, G.; Schinazi, R.F. COVID-19: Discovery, Diagnostics and Drug Development. J. Hepatol. 2020. [CrossRef] [PubMed]

20. Mohammadi, A.; Esmaeilzadeh, E.; Li, Y.; Bosch, R.J.; Li, J.Z. SARS-CoV-2 Detection in Different Respiratory Sites: A Systematic Review and Meta-Analysis. EBioMedicine 2020, 59. [CrossRef]

21. Wölfel, R.; Corman, V.M.; Guggemos, W.; Seilmaier, M.; Zange, S.; Müller, M.A.; Niemeyer, D.; Jones, T.C.; Vollmar, P.; Rothe, C.; et al. Virological Assessment of Hospitalized Patients with COVID-2019. Nature 2020, 581, 465-469. [CrossRef]

22. Lee, R.A.; Herigon, J.C.; Benedetti, A.; Pollock, N.R.; Denkinger, C.M. Performance of Saliva, Oropharyngeal Swabs, and Nasal Swabs for SARS-CoV-2 Molecular Detection: A Systematic Review and Meta-Analysis. medRxiv 2020. [CrossRef]

23. Hayer, J.; Kasapic, D.; Zemmrich, C. Real-World Clinical Performance of Commercial SARS-CoV-2 Rapid Antigen Tests in Suspected COVID-19: A Systematic Meta-Analysis of Available Data as per November 20. medRxiv 2020. [CrossRef]

24. Czumbel, L.M.; Kiss, S.; Farkas, N.; Mandel, I.; Hegyi, A.; Nagy, Á.; Lohinai, Z.; Szakács, Z.; Hegyi, P.; Steward, M.C.; et al. Saliva as a Candidate for COVID-19 Diagnostic Testing: A Meta-Analysis. Front. Med. 2020, 7. [CrossRef] [PubMed]

25. Calame, A.; Mazza, L.; Renzoni, A.; Kaiser, L.; Schibler, M. Sensitivity of Nasopharyngeal, Oropharyngeal, and Nasal Wash Specimens for SARS-CoV-2 Detection in the Setting of Sampling Device Shortage. Eur. J. Clin. Microbiol. Infect. Dis. 2020, 1-5. [CrossRef]

26. Jeong, H.W.; Kim, S.-M.; Kim, H.-S.; Kim, Y.-I.; Kim, J.H.; Cho, J.Y.; Kim, S.; Kang, H.; Kim, S.-G.; Park, S.-J.; et al. Viable SARSCoV-2 in Various Specimens from COVID-19 Patients. Clin. Microbiol. Infect. 2020, 26, 1520-1524. [CrossRef]

27. Ranoa, D.R.E.; Holland, R.L.; Alnaji, F.G.; Green, K.J.; Wang, L.; Brooke, C.B.; Burke, M.D.; Fan, T.M.; Hergenrother, P.J. Saliva-Based Molecular Testing for SARS-CoV-2 That Bypasses RNA Extraction. bioRxiv 2020. [CrossRef]

28. To, K.K.-W.; Tsang, O.T.-Y.; Yip, C.C.-Y.; Chan, K.-H.; Wu, T.-C.; Chan, J.M.-C.; Leung, W.-S.; Chik, T.S.-H.; Choi, C.Y.-C.; Kandamby, D.H.; et al. Consistent Detection of 2019 Novel Coronavirus in Saliva. Clin. Infect. Dis. 2020, 71, 841-843. [CrossRef]

29. Iwasaki, S.; Fujisawa, S.; Nakakubo, S.; Kamada, K.; Yamashita, Y.; Fukumoto, T.; Sato, K.; Oguri, S.; Taki, K.; Senjo, H.; et al. Comparison of SARS-CoV-2 Detection in Nasopharyngeal Swab and Saliva. J. Infect. 2020, 81, e145-e147. [CrossRef]

30. Wyllie, A.L.; Fournier, J.; Casanovas-Massana, A.; Campbell, M.; Tokuyama, M.; Vijayakumar, P.; Warren, J.L.; Geng, B.; Muenker, M.C.; Moore, A.J.; et al. Saliva or Nasopharyngeal Swab Specimens for Detection of SARS-CoV-2. N. Engl. J. Med. 2020, 383, 1283-1286. [CrossRef]

31. Lippi, G.; Henry, B.M.; Sanchis-Gomar, F.; Mattiuzzi, C. Updates on Laboratory Investigations in Coronavirus Disease 2019 (COVID-19). Acta Bio Med. 2020, 91, e2020030. [CrossRef]

32. Moreira, V.M.; Mascarenhas, P.; Machado, V.; Botelho, J.; Mendes, J.J.; Taveira, N.; Almeida, M.G. Diagnosis of SARS-Cov-2 Infection Using Specimens Other than Naso- and Oropharyngeal Swabs: A Systematic Review and Meta-Analysis. medRxiv 2021. [CrossRef] 
33. Bastos, M.L.; Perlman-Arrow, S.; Menzies, D.; Campbell, J.R. The Sensitivity and Costs of Testing for SARS-CoV-2 Infection With Saliva Versus Nasopharyngeal Swabs. Ann. Intern. Med. 2021. [CrossRef]

34. Bwire, G.M.; Majigo, M.V.; Njiro, B.J.; Mawazo, A. Detection Profile of SARS-CoV-2 Using RT-PCR in Different Types of Clinical Specimens: A Systematic Review and Meta-Analysis. J. Med. Virol. 2020. [CrossRef]

35. Van Doorn, A.S.; Meijer, B.; Frampton, C.M.A.; Barclay, M.L.; de Boer, N.K.H. Systematic Review with Meta-analysis: SARS-CoV-2 Stool Testing and the Potential for Faecal-oral Transmission. Aliment. Pharmacol. Ther. 2020. [CrossRef]

36. Chan, V.W.-S.; Chiu, P.K.-F.; Yee, C.-H.; Yuan, Y.; Ng, C.-F.; Teoh, J.Y.-C. A Systematic Review on COVID-19: Urological Manifestations, Viral RNA Detection and Special Considerations in Urological Conditions. World J. Urol. 2020, 1-12. [CrossRef]

37. Aggarwal, K.; Agarwal, A.; Jaiswal, N.; Dahiya, N.; Ahuja, A.; Mahajan, S.; Tong, L.; Duggal, M.; Singh, M.; Agrawal, R.; et al. Ocular Surface Manifestations of Coronavirus Disease 2019 (COVID-19): A Systematic Review and Meta-Analysis. PLoS ONE 2020, 15, e0241661. [CrossRef] [PubMed]

38. Cao, K.; Kline, B.; Han, Y.; Ying, G.; Wang, N.L. Current Evidence of 2019 Novel Coronavirus Disease (COVID-19) Ocular Transmission: A Systematic Review and Meta-Analysis. Biomed. Res. Int. 2020, 2020. [CrossRef]

39. Ling, X.C.; Kang, E.Y.-C.; Lin, J.-Y.; Chen, H.-C.; Lai, C.-C.; Ma, D.H.-K.; Wu, W.-C. Ocular Manifestation, Comorbidities, and Detection of Severe Acute Respiratory Syndrome-Coronavirus 2 from Conjunctiva in Coronavirus Disease 2019: A Systematic Review and Meta-Analysis. Taiwan J. Ophthalmol. 2020, 10, 153-166. [CrossRef]

40. Ulhaq, Z.S.; Soraya, G.V. The Prevalence of Ophthalmic Manifestations in COVID-19 and the Diagnostic Value of Ocular Tissue/Fluid. Graefes Arch. Clin. Exp. Ophthalmol. 2020, 258, 1351-1352. [CrossRef]

41. Andersson, M.; Carcamo, C.V.A.-; Auckland, K.; Baillie, J.K.; Barnes, E.; Beneke, T.; Bibi, S.; Carroll, M.; Crook, D.; Dingle, K.; et al. SARS-CoV-2 RNA Detected in Blood Samples from Patients with COVID-19 Is Not Associated with Infectious Virus. medRxiv 2020. [CrossRef]

42. Guo, C.-C.; Mi, J.-Q.; Nie, H. Seropositivity Rate and Diagnostic Accuracy of Serological Tests in 2019-NCoV Cases: A Pooled Analysis of Individual Studies. Eur. Rev. Med. Pharmacol. Sci. 2020, 24, 10208-10218. [CrossRef]

43. SARS-CoV-2 Testing. Available online: https://www.covid19treatmentguidelines.nih.gov/overview/sars-cov-2-testing/ (accessed on 24 December 2020).

44. Wong, M.C.; Huang, J.; Lai, C.; Ng, R.; Chan, F.K.L.; Chan, P.K.S. Detection of SARS-CoV-2 RNA in Fecal Specimens of Patients with Confirmed COVID-19: A Meta-Analysis. J. Infect. 2020, 81, e31-e38. [CrossRef] [PubMed]

45. Kutti-Sridharan, G.; Vegunta, R.; Vegunta, R.; Mohan, B.P.; Rokkam, V.R.P. SARS-CoV2 in Different Body Fluids, Risks of Transmission, and Preventing COVID-19: A Comprehensive Evidence-Based Review. Int. J. Prev. Med. 2020, 11. [CrossRef]

46. Xie, C.; Jiang, L.; Huang, G.; Pu, H.; Gong, B.; Lin, H.; Ma, S.; Chen, X.; Long, B.; Si, G.; et al. Comparison of Different Samples for 2019 Novel Coronavirus Detection by Nucleic Acid Amplification Tests. Int. J. Infect. Dis. 2020, 93, 264-267. [CrossRef]

47. Jayamohan, H.; Lambert, C.J.; Sant, H.J.; Jafek, A.; Patel, D.; Feng, H.; Beeman, M.; Mahmood, T.; Nze, U.; Gale, B.K. SARS-CoV-2 Pandemic: A Review of Molecular Diagnostic Tools Including Sample Collection and Commercial Response with Associated Advantages and Limitations. Anal. Bioanal. Chem. 2020, 1-23. [CrossRef] [PubMed]

48. Kashi, A.H.; De la Rosette, J.; Amini, E.; Abdi, H.; Fallah-Karkan, M.; Vaezjalali, M. Urinary Viral Shedding of COVID-19 and Its Clinical Associations: A Systematic Review and Meta-Analysis of Observational Studies. Urol. J. 2020, 17, 433-441. [CrossRef] [PubMed]

49. Roshandel, M.R.; Nateqi, M.; Lak, R.; Aavani, P.; Sari Motlagh, R.; Shariat, S.F.; Aghaei Badr, T.; Sfakianos, J.; Kaplan, S.A.; Tewari, A.K. Diagnostic and Methodological Evaluation of Studies on the Urinary Shedding of SARS-CoV-2, Compared to Stool and Serum: A Systematic Review and Meta-Analysis. Cell. Mol. Biol. 2020, 66, 148-156. [CrossRef]

50. Belser, J.A.; Rota, P.A.; Tumpey, T.M. Ocular Tropism of Respiratory Viruses. Microbiol. Mol. Biol. Rev. 2013, 77, 144-156. [CrossRef] [PubMed]

51. Kaya, H.; Çalışkan, A.; Okul, M.; Sarı, T.; Akbudak, İ.H. Detection of SARS-CoV-2 in the Tears and Conjunctival Secretions of Coronavirus Disease 2019 Patients. J. Infect. Dev. Ctries 2020, 14, 977-981. [CrossRef] [PubMed]

52. Mahmoud, H.; Ammar, H.; El Rashidy, A.; Ali, A.H.; Hefny, H.M.; Mounir, A. Assessment of Coronavirus in the Conjunctival Tears and Secretions in Patients with SARS-CoV-2 Infection in Sohag Province, Egypt. Clin. Ophthalmol. 2020, 14, $2701-2708$. [CrossRef] [PubMed]

53. Atum, M.; Boz, A.A.E.; Çakır, B.; Karabay, O.; Köroğlu, M.; Öğütlü, A.; Alagöz, G. Evaluation of Conjunctival Swab PCR Results in Patients with SARS-CoV-2 Infection. Ocul. Immunol. Inflamm. 2020, 28, 745-748. [CrossRef]

54. Seah, I.Y.J.; Anderson, D.E.; Kang, A.E.Z.; Wang, L.; Rao, P.; Young, B.E.; Lye, D.C.; Agrawal, R. Assessing Viral Shedding and Infectivity of Tears in Coronavirus Disease 2019 (COVID-19) Patients. Ophthalmology 2020, 127, 977-979. [CrossRef]

55. Wang, H.; Ai, J.; Loeffelholz, M.J.; Tang, Y.-W.; Zhang, W. Meta-Analysis of Diagnostic Performance of Serology Tests for COVID-19: Impact of Assay Design and Post-Symptom-Onset Intervals. Emerg. Microbes. Infect. 2020, 9, 2200-2211. [CrossRef] [PubMed]

56. Centers for Disease Control and Prevention Coronavirus Disease 2019 (COVID-19)—Guidance for Dental Settings. Available online: https:/ / www.cdc.gov/ coronavirus/2019-ncov/hcp/dental-settings.html (accessed on 3 March 2021).

57. Oran, D.P.; Topol, E.J. Prevalence of Asymptomatic SARS-CoV-2 Infection: A Narrative Review. Ann. Intern. Med. 2020, 173, 362-367. [CrossRef] 
58. Gandhi, M.; Yokoe, D.S.; Havlir, D.V. Asymptomatic Transmission, the Achilles' Heel of Current Strategies to Control Covid-19. N. Engl. J. Med. 2020, 382, 2158-2160. [CrossRef]

59. Lamberghini, F.; Trifan, G.; Testai, F.D. SARS-CoV-2 Infection in Asymptomatic Pediatric Dental Patients. J. Am. Dent. Assoc. 2021. [CrossRef]

60. Conway, D.I.; Culshaw, S.; Edwards, M.; Clark, C.; Watling, C.; Robertson, C.; Braid, R.; O’Keefe, E.; McGoldrick, N.; Burns, J.; et al. SARS-CoV-2 Positivity in Asymptomatic-Screened Dental Patients. medRxiv 2021. [CrossRef] 